\title{
A Study to ascertain the Optimum Yield from Groundwater Source in the Eastern Part of Kolkata Municipal Corporation Area in West Bengal, India
}

Pankaj K. Roy ${ }^{1 *}$, Gourab Banerjee ${ }^{1}$, Asis Mazumdar ${ }^{1}$, Amlanjyoti Kar $^{2}$, Arunabha Majumder ${ }^{1}$, Malabika Biswas Roy ${ }^{3}$

\begin{abstract}
The increasing stress on fresh water resources due to ever-rising demands and profligate uses as well as growing population and industrial establishment of Kolkata is an issue of great concern. The purpose of this study is to make a quantitative estimate of the available groundwater resources in the eastern part of Kolkata for efficient utilization and management of groundwater resources. The methodology involved the investigation, drilling, lowering, collection and analysis of main well and observation wells data and groundwater quality as well. Based upon the study of lithological logs as also the electrical log, the sub-surface deposition of the assembly pipes have been determined. The results indicate that the aquifers are composite and composed of sands and overlying silts/clay beds. Long term Tests pumping indicate that the main well may be capable of a long term discharge rate of $120 \mathrm{~m}^{3} / \mathrm{hr}$ restricted at $120 \mathrm{~m}$ and $156.65 \mathrm{~m}$. The aquifer parameters from the study area are estimated from the analysis of short and long durations pumping test data. For the alluvial aquifer, transmissivity of $1491 \mathrm{~m}^{2} / \mathrm{d}$, hydraulic conductivity of $49.7 \mathrm{~m} / \mathrm{d}$ and storage coefficient of 0.0064 are recommended found by using different methods. Long duration pumping tests have indicated that the maximum drawdown in water table by $4.89 \mathrm{~m}$ may be achievable by radius of influence about $682 \mathrm{~m}$. After the closure of pumping operation, recuperation test was also carried out in the main wells as well as also from observation wells. Recovery test was monitored for $20 \mathrm{hrs}$ after closure of pumping. Slope of the residual drawdown from $t / t$ ' indicated aquifer transmissivity of $1322 \mathrm{~m}^{2} / \mathrm{d}$ and therefore hydraulic conductivity of the alluvial sand aquifer is $44 \mathrm{~m} / \mathrm{d}$ having an aquifer thickness of $30 \mathrm{~m}$. The physico-chemical and bacteriological analysis of groundwater of two pumping wells were tested and the results showed the groundwater must be disinfected before supplying to the consumers.
\end{abstract}

Keywords: optimum yield, sustainable source, groundwater, KMC, pumping wells

1School of Water Resources Engineering, Jadavpur University, Kolkata, India

2Central Groundwater Board, Ministry of Water Resources, Eastern Region, Kolkata, India

3GCBT College Habra, West Bengal, India

*Corresponding author: pk1roy@yahoo.co.in 


\section{Introduction}

West Bengal is the only state in India that stretches from Mountain to the Sea and truly a "Asamudra himachalam" state as the meaning goes. West Bengal has a very good groundwater potential. The reason of such affluence is due to her geographical location, high rainfall and favorable geological setting. The state have land area of about $2.7 \%$ but have about $6 \%$ of total replenishible groundwater resources of India. Groundwater is the most exploited resource in west Bengal particularly in agriculture sector With the introduction of water intensive high yielding variety, the need for groundwater have skyrocketed (PGWSWB, 2011).

In spite of having high groundwater reserve, exploitation of the resources in West Bengal shot up to such level that 80's decade first witnessed the sign of depletion of groundwater level in some blocks of Murshidabad, Burdwan, Medinipur, Hooghly where pre-monsoon water level dropped below the centrifugal pumping limit and hand tubewells went dry. Introduction of Submersible motor driven pump though came as a blessing to the cultivators, for it can draw water from far deeper depth - caused further lowering of groundwater level (PGWSWB, 2011).

The water supply for Kolkata Municipal Corporation (KMC) area comprises conjunctive use of treated surface water of Hooghly River and tapping of groundwater by deep tube wells and hand tube wells. The KMC area is situated on the unconsolidated sediment of the Lower Bengal Delta. Typically these sediments comprise number of successions of clay, silt and sand and their mixtures in different proportions. KMC owned 264 nos of large dia $(203 \mathrm{~mm})$ tube wells fitted with $20 \mathrm{hp}$ submersible pump and 10000 nos small dia $(40 \mathrm{~mm})$ tube wells fitted with hand pump, which are operating in KMC area as on December, 2006. Withdrawl from large dia tubewell is about 112.5 MLD and hand pump fitted small dia tube well is 21.4 MLD. Besides KMC owned Tube wells, there are 5831 nos of private owned small dia $(101 \mathrm{~mm})$ tube wells fitted with 1 to $2 \mathrm{hp}$ pump in KMC area. Withdrawl from these tube wells works out to be 735 MLD. Thus a total of 868.9 MLD of groundwater is being withdrawl in KMC area (Mishra and Ghosh, 2009).

In the present area clay black/ clay yellow ranging in thickness from $15 \mathrm{~m}$ to $80 \mathrm{~m}$ occurs at the top. This clay is underlain by fine medium and coarse sand. However thickening and thinning of clay, silt and sand are observed in different sections. The groundwater occurs under confined conditions wherein the aquifer forming sand usually occurs between $50 \mathrm{~m}$ to $130 \mathrm{~m}$ bgl. However a shallow aquifer of fine to medium sand is observed between $20 \mathrm{~m}$ to $40 \mathrm{~m}$ bgl. The data on the aquifer 
characteristics of these sand bodies is somewhat limited and the transmissivity value ranges from 1680 to $2160 \mathrm{~m}^{2} /$ day. The groundwater flow is consequently observed to be ranged from 40 to $140 \mathrm{~m}^{3}$ /day (KMC, 2007)

From 2005 KMC started replacing gradually the groundwater supply by surface water supply. As a result there is a reduction in the quantum of groundwater withdrawal by KMC owned tube wells from 2005. In 2006 groundwater withdrawal by KMC owned tube wells come down to 133.90 MLD (KMC, 2007). Considering the fact that as yet pipeline supply of surface water is not available for large area of the $\mathrm{KMC}$, it becomes necessary to reassess the groundwater scenario of the KMC area.

Withdrawal of groundwater in KMC area by KMC owned tube wells increased progressively from 121.5 MLD in 1986 to 209.7 MLD in 1998 and it continued up to 2004. As a result the piezometric surface becomes deepest around Park Street forming a trough in Central Kolkata around Park Street, Rajabazar, Fort William etc due to excessive withdrawal of groundwater as well as due to interference effect of closely spaced tube wells running simultaneously. The long term trend of ground water level in this part indicates a falling trend in both pre and post monsoon period. There is fall of 7 to $11 \mathrm{~m}$ in groundwater level in last 45 years from 1958 to 2003. From 2005 KMC started replacing gradually the groundwater supply by surface water supply. As a result there is a reduction in the quantum of groundwater withdrawal by KMC tube wells from 2005. The impact is very positive on groundwater regime, as the area of the groundwater trough started reducing.

Initially surface water supply was made from Palta pumping station 27 MLD in 1869). A quantity of 1161 MLD (258 MGD) (2006) of treated surface water from river Hugli is being supplied in KMC area through four pumping stations at Palta, Garden Reach, Jorabagan and Watganj (KMC, 2007)

As on December $2006 \mathrm{KMC}$ owned 264 nos large dia $(300 \mathrm{~mm})$ tube wells fitted with $20 \mathrm{hp}$ submersible pump with a discharge of 0.486 MLD and 10,000 nos small dia $(40 \mathrm{~mm})$ tube wells fitted with hand pump with a discharge of 0.0016 MLD, which are operating in KMC area. Besides KMC owned tube wells, there are 5840 nos of Private owned small dia $(40-200 \mathrm{~mm})$ tube wells fitted with 1 to 12 hp pump with discharge varying from 0.0189 to 0.27 MLD in KMC area. Withdrawal from Private owned tube wells and hand pump fitted tube wells works out to be 160.9 MLD and 16 MLD respectively. As per KMC withdrawal from KMC owned large dia tube wells is 128.30 MLD during 2006. Thus a total of 305.20 MLD of groundwater is being withdrawn in KMC area. The withdrawal of groundwater by KMC owned tube wells from 1986 to 2006 is as follows in Table 1 
Table 1. Groundwater withdrawn by KMC area (KMC, 2007)

\begin{tabular}{llll}
\hline Year & No. of Groundwater structure & \multicolumn{2}{c}{$\begin{array}{c}\text { Total groundwater withdrawn } \\
\text { (MLD) }\end{array}$} \\
\cline { 1 - 3 } 1986 & Deep Tube Well & $\begin{array}{l}\text { Shallow Tube Well (Hand } \\
\text { pump fitted) }\end{array}$ & \\
\cline { 2 - 3 } 1991 & 285 & 5000 & 121.50 \\
1993 & 308 & 10500 & 184.95 \\
1998 & 325 & 11877 & 202.72 \\
2006 & 264 & 12000 & 209.70 \\
\hline
\end{tabular}

The study area is located in the eastern part of KMC area and underlain by thick alluvium deposited by the river Hugli and its tributaries. The Recent sequences of alternation of sand of different size, clay, silt are deposited in the basin. Because of marine transgression and regression in the geologic past, both the saline and fresh waters are available in the aquifers disposed in the subsurface. Since an urban settlement is in the process of making, to sanction withdrawal of groundwater to meet the purpose of drinking and domestic use in the periphery of eastern part of KMC area, School of Water Resources Engineering was entrusted with the responsibility to recommend the feasible quantum of water, what the urban establishment can withdraw.

The work has been carried out in two phases and the first phase was initiated from August, 2010 and continued till February, 2011 and the next phase of the work was initiated from August, 2011 and continued till December, 2011.

The present study highlights the necessary study at site and provided the detailed technical data related to hydro-geological parameters including chemical quality of groundwater. The yield test is carried out in connection to ascertain the response of aquifer to pumping. The exploration boring has been done and field trials for the electro logging test were conducted at the main well located at eastern part of Kolkata. On the basis of field study and investigations, data collection, collection and analysis a detailed report has been prepared highlighting the optimum yield from groundwater resource in the locality. 


\section{Study Area}

Technical study for findings different Hydrological parameters including chemical quality of groundwater to ascertain the optimum yield from groundwater source in the locality of eastern part of Kolkata having latitude of $\mathrm{N} \mathrm{22} 2^{0} 30^{\prime} 36.2^{\prime \prime}$ and longitude of $\mathrm{E} 88^{0} 24^{\prime} 48.1^{\prime \prime}$ as shown in Figure 1. KMC area is bounded by river Hugli in the Northwest, South 24 Parganas district in the south and southwest, Salt Lake City in the east and North 24 Parganas district in the north. The area falls

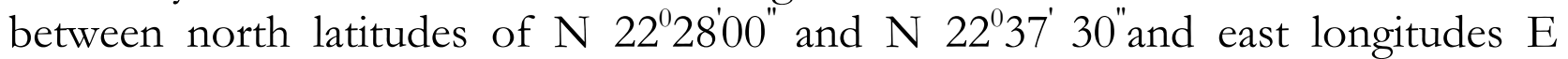
$88^{\circ} 17^{\prime} 30^{\prime \prime}$ and $\mathrm{E} 88^{\circ} 25^{\prime} 00^{\prime \prime}$. KMC covers an area of 187.33 sq. $\mathrm{km}$ and is divided into141 wards and 15 nos of borough.

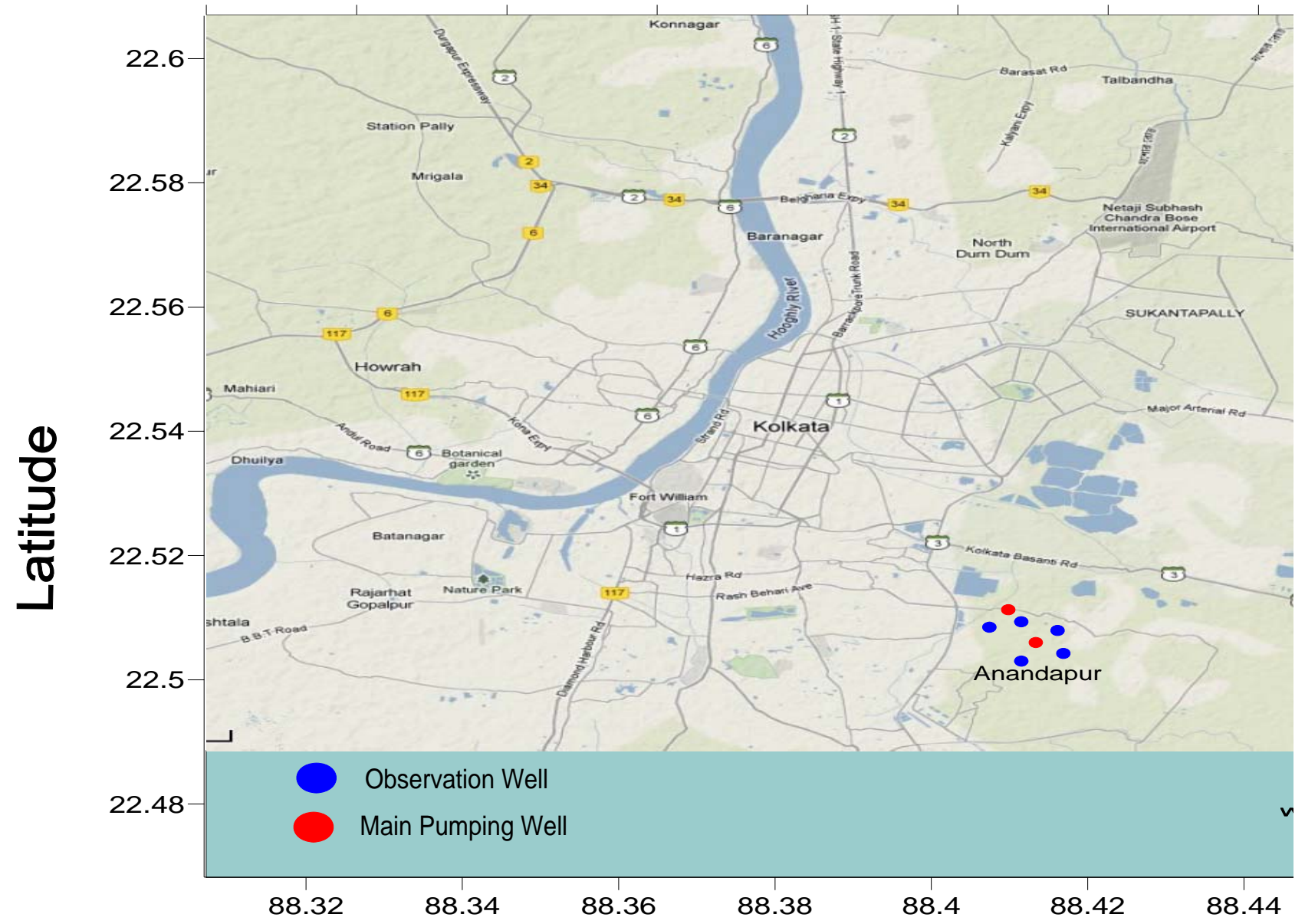

Longitude

Figure 1. Study area showing main wells and observation wells

Initially the city covered an area of 104 sq.km with 100 nos of wards, which subsequently extended to the present area after including 44 nos of more wards from the municipalities of South Suburban, Garden Reach and Jadavpur in 1983. 
Due to the influx of refugees of the East Pakistan (Bangladesh) and various other Socio-economic reasons, the demographic features were subjected to a vast change. There had been disproportionate increase of population here and there since independence. Because of its location within the KMC and its closeness to the city of Kolkata, people from the adjoining villages and other areas have infiltrated into this urban agglomeration which includes pockets of high income group, middle income group, economically worker section and marginally below poverty line. Therefore improvements of municipal facilities are truly need-based. Besides, because of rapid pace of urbanization with consequential eviction of the poor, many people swarmed into this municipal area where land was affordably cheap.

\subsection{Land Use}

Kolkata Municipal Area is located in the lower deltaic plain of the composite Ganga-Bhagirathi delta in the lower pare of Bengal basin and is covered by Quaternary alluvial sediment brought down by Ganga-Bhagirtahi river system. The basement rock lies at greater depth. Two regionally extensive clay beds are present throughout KMC area within the depth of $400 \mathrm{~m}$ bgl. The depth of occurrence of the basal clay varies from place to place but in general it occurs from 300 to $450 \mathrm{~m}$ bgl and the top clay bed (10 to more than $60 \mathrm{~m}$ thick) overlies the entire alluvium sequence in KMC area. The area is underlain by $762 \mathrm{~m}$ thick unconsolidated alluvium, which overlies a huge pile of unconsolidated to semi-consolidated sediments indicates subsidence of the basin along with sedimentation. The area is underlain by Quaternary alluvium compromising several cycles of sand silt and clay shows variation in both vertical as well as in horizontal sections (KMC, 2007).

\subsection{Geomorphology and Soil types}

Kolkata forms a part of the lower deltaic plains of the Ganga- Bhagirathi river system. It is a typical deltaic flat land with surface elevation ranging between 3.5 to $6 \mathrm{~m}$ above mean seal level. Several low lying depressions in the form of marshes, shallow lakes occur within the city and most of these represent river scars of the post river channels of Bhagirathi. The master slope of the land is towards south. Younger levee, deltaic plain, interdistributory marsh, paleo channels and younger levee adjacent to river Hoogli and older levee on both sides of the old Adi Ganga are the important geo-morphological units present in the area. The area is covered with younger alluvial soil mainly of silty \& clayey loams (KMC, 2007). 


\subsection{Hydrogeology}

The area is underlain by $762 \mathrm{~m}$ thick unconsolidated alluvium, which overlies a huge pile of unconsolidated to semi-consolidated sediments deposited on the basement. The structure and lithology of the sediments indicates number of pulses of sedimentation, marine transgression and regression and tectonic uplift from Cretaceous to Pleistocene times. The study of the lithological logs of borehole data indicates that the upper $300 \mathrm{~m}$ of sediments are of Quaternary age but the exact boundary between the Quaternary and Tertiary sediments could not be established due paucity of data. The Quaternary alluvium comprising several cycles of sand, silt and clay and shows facies variation in both vertical as well as in horizontal sections (KMC, 2007)

Thin lenses of very fine grained sand and silt in the silt clay layer also occur above the top clay layer at some places around Ballyganj, Tollyganj, Tijola, Dhakuria, Kasba, Santoshpur, Garia, Behala, Barish and Thakurpur in the marshy/swampy lands. The thickness of these sand and silt layers varies from place to place. In the levee deposits along the bank of river Hugli lenses of sand of fine to coarse grained are also present above the top clay bed at some places. The thickness of this sand bed also varies from place to place (KMC, 2007).

\section{Methodology}

Keeping the above objective in view the investigation work was initiated with the reconnaitory traverse in the eastern part of KMC area. It was assumed that since the area is underlain by thick gangetic alluvium, it is very difficult to ascertain the characteristics of the aquifers without groundwater exploration. In this regard, it is to mention that State Water Investigation Directorate (SWID), Govt. of West Bengal, Kolkata advocated to carry out the investigation with the exploratory tubewell having dimension $150 \mathrm{~mm} \times 100 \mathrm{~mm} \times 200 \mathrm{~m}$ depth (bgl). It is postulated that in order to obtain the optimum yield heavy pumping is to be imposed from the exploratory well in the locality so that the maximum cone of depression and radius of influence in the adjoining areas can be determined and thereby future scenario can be projected with reasonable accuracy. In this connection, new well dimension (300 mm x $200 \mathrm{~mm} \times 200 \mathrm{~m}$ depth (bol)) has been proposed by School of Water Resources Engineering (SWRE), Jadavpur University (JU), Kolkata which may accommodate the desired pumping.

To carry out the investigation a well field consisting of a main (pumping) well (latitude 22030'36.2" and longitude $88^{\circ} 24^{\prime} 48.1^{\prime \prime}$ ) with two observation wells (dimension $80 \mathrm{~mm}$ × $50 \mathrm{~mm}$ x $200 \mathrm{~m}$ depth (bgl)) (latitude 22 30'35.9" and $22^{\circ} 30^{\prime} 33.5^{\prime \prime}$ and longitude $88^{\circ} 24^{\prime} 49.3^{\prime \prime}$ and $\left.88^{\circ} 24^{\prime} 49.2^{\prime \prime}\right)$ was proposed to be 
constructed in the study area. However, subsequently another observation well with identical dimension has also been constructed for the study.

Accordingly drilling of the first main well up to $200 \mathrm{~m}$ depth was achieved by reverse rotary drilling rig. Before lowering the assembly, electrical logging, of the borehole was done. Based upon the study of lithological log as also the electrical $\mathrm{log}$, the sub-surface disposition of the assembly pipes consisting of blank and slotted section were determined. The assembly of uPVC pipes were lowered for well construction purpose. In this regard, it is worth to mention that although the targeted depth was kept at $200 \mathrm{~m}$, on critical examination of the electrical log, it was decided that the depth of the well may be restricted up to $120 \mathrm{~m}$ as the immediate underlying aquifers might hold brackish groundwater in patches. Accordingly the observation wells (piezometers) were constructed in the well field surrounding the proposed pumping well.

To explore the groundwater potential of the aquifer in the area under consideration, further investigation has been resumed after thorough survey of the present site condition, a new well (second pumping well) (latitude $24^{\circ} 16^{\prime} 13.9^{\prime \prime}$ "and longitude $\left.88^{0} 16^{\prime} 02.3^{\prime \prime}\right)$ was proposed to investigate further deep in the ground up to or below $400 \mathrm{~m}$. Again, to carry out the investigation a new well field consisting of a main (second pumping) well $\left(300 \mathrm{~mm}\right.$ x $200 \mathrm{~mm}$ ) (latitude $24^{0} 16^{\prime} 13.9^{\prime \prime}$ and longitude $\left.88^{\circ} 16^{\prime} 02.3^{\prime \prime}\right)$ with two observation wells (dimension $50 \mathrm{~mm}$ x $50 \mathrm{~mm}$ ) (latitude $22^{\circ} 30^{\prime} 37.1^{\prime \prime}$ and $24^{\circ} 16^{\prime} 13.6^{\prime \prime}$ and longitude $88^{\circ} 24^{\prime} 37.6^{\prime \prime}$ and $\left.88^{\circ} 16^{\prime} 01.9^{\prime \prime}\right)$ was proposed to be constructed in the study area.

Accordingly drilling, lowering the assembly, electrical logging, lithological logs of the borehole of the second main well up to $422.05 \mathrm{~m}$ depth was achieved by direct rotary drilling rig. This study highlighted that although the targeted depth was kept as $422.05 \mathrm{~m}$, on critical examination of the electrical log, it was decided that the depth of the well may be restricted up to $156.65 \mathrm{~m}$ as the immediate underlying aquifers were seen to hold brackish to saline water in them. Accordingly the observation wells (piezometers) were constructed in the field surrounding the proposed pumping well.

\section{Results and Discussions}

\subsection{First Phase of Hydrological Tests-First Pumping Well}

In order to adjudge various hydrological parameters as desired by SWID, pumping tests were carried out for duration of 170 and 295 minutes respectively. In the first occasion step drawdown test was conducted at variable discharges of 72, 97 and $107 \mathrm{~m}^{3} / \mathrm{hr}$ respectively. During the variable discharges, unsteady condition of aquifer was noticed. After cessation of pumping, recuperation test was also carried 
out in the main as also from two observation wells and the same was completed. Accordingly the piezometric level data as obtained from the main as well as the observation wells were plotted in semi-log and log-log papers as opined by various proponents in groundwater hydrology like Thiem, Cooper and Jacob and Chow. The data plots and their matching with the master curves has facilitated the determination of various aquifer parameters like hydraulic conductivity (K), Transmissivity (T), Storativity (S)/specific yield (Ss) etc. The cone of depression with respect to the maximum discharge of $107 \mathrm{~m}^{3} / \mathrm{hr}$ for which testing was carried out in the area is found $922.4 \mathrm{~m}$. The drawdowns versus yield are shown in Table 2.

\section{Table 2. Drawdown versus yield (pumping duration-170 and 295 minutes)}

Discharge Drawdown (m) for Drawdown $(\mathrm{m})$ for $\operatorname{Drawdown}(\mathrm{m})$ for $\left(\mathrm{m}^{3} / \mathrm{hr}\right) \quad$ Main well $\quad$ Observation well-1 Observation well-2

$\begin{array}{llll}107 & 4.81 & 0.33 & 0.28\end{array}$

From the above pumping studies, it was seen that a long duration pumping tests with another or more observation wells would have been more appropriate to adjudge the actual potentiality of the aquifer and its influence on the static water levels in the perspective of future projected scenario.

Accordingly long duration pumping test for 72 hrs (4320 minutes) was conducted. Prior to that one more observation well having identical dimension was constructed. Similarly piezometric levels were monitored during the pumping period from the main well and the observation wells. After closure of pumping operation, recuperation test was also carried out in the main as also in three observation wells and the same was completed. The data obtained from the long duration test are being compiled and analyzed following various methods as stated above (Thiem, Cooper \& Jacob and Chow) and deduction of aquifer parameters are underway. The drawdowns versus yield are shown in Table 3 . In the first phase one number of production well (first pumping well) was constructed based upon which recommendation for withdrawal of $50 \mathrm{~m}^{3} / \mathrm{hr}$ of water from a depth of $120 \mathrm{~m}$ (bgl) was advocated.

Table 3. Drawdown versus yield (Long duration test-4320 minutes)

\begin{tabular}{|c|c|c|c|c|c|}
\hline $\begin{array}{l}\text { Discharge } \\
\left(\mathrm{m}^{3} / \mathrm{hr}\right)\end{array}$ & $\begin{array}{l}\text { Drawdown }(\mathrm{m}) \\
\text { Main well }\end{array}$ & for & $\begin{array}{l}\text { Drawdown (m) } \\
\text { for } \\
\text { Observation } \\
\text { well-1 }\end{array}$ & $\begin{array}{l}\text { Drawdown (m) } \\
\text { for } \\
\text { Observation } \\
\text { well-2 }\end{array}$ & $\begin{array}{l}\text { Drawdown (m) } \\
\text { for Observation } \\
\text { well-3 }\end{array}$ \\
\hline 120 & 4.89 & & 0.82 & 0.40 & 0.573 \\
\hline
\end{tabular}




\subsection{Second Phase of Hydrological Study: Second Pumping Well}

From the first phase of study, it has been decided to go for exploring the deeper aquifer with static water levels which are yet to be tapped in the locality.

In order to adjudge the aquifer characteristic of the aquifers, as also to verify the quality of groundwater available in different sub-surface geological sections, deep drilling up to $400 \mathrm{~m}$ depth or further below ground level was undertaken. The exploratory drilling generated drill cuttings and peer study of geological litho logs followed by electrical logging of borehole have unraveled the quality of groundwater available in the subsurface at various depths and aquifers as also the cumulative thickness of the fresh water bearing aquifers.

To find out the existence of any further fresh water bearing aquifer down below the depth of $200 \mathrm{~m}$ (the depth of former production well), deep explorations were undertaken down to the depth of $422.05 \mathrm{~m}$. The study revealed that no further aquifer is existing in the area below the depth of $155 \mathrm{~m}$. The total cumulative thickness of the fresh water bearing aquifer in the area is $95 \mathrm{~m}$. It may also be opined that besides few small clay/silt intercalations, the entire thickness of fresh water bearing aquifer may be assumed as a single aquifer. The elevations from MSL of the drilling points were found out from GPS. From the altitudinal data as also from the study of the litholog and the electro-graphs evolved from the electrical logging, the inclination of the geological formations has been assumed. The average inclination of the strata has been deduced as $4^{0} 39^{\prime} 44^{\prime \prime}$.

While designing the tube well the position of the strainer has been kept below the depth of the former tube well. Here the depth of the tube well is $156.65 \mathrm{~m}$ when the position of the strainer is considered in between $123.50 \mathrm{~m}$ to $153.50 \mathrm{~m}$. From the above statement, it is clear that although the second production well is tapping the same potential aquifer, it is tapping the water flowing at an appreciable depth below the portion of the aquifer tapped by the main well constructed in the first phase.

Akin to the previous observations made, to deduce the zone of influence, two new piezometers (observation tube well) were constructed in various directions of the main well. Long duration pumping tests for $72 \mathrm{hrs}$ were conducted in the second main well. Drawdown and recuperation data were measured from the main well as well as the observation wells. The pump was operated at different discharges 50 $\mathrm{m}^{3} / \mathrm{hr}, 83 \mathrm{~m}^{3} / \mathrm{hr}$ and $120 \mathrm{~m}^{3} / \mathrm{hr}$ and accordingly the drawdown of the main well was recorded $1.8 \mathrm{~m}, 3.8 \mathrm{~m}$ and $4.88 \mathrm{~m}$ respectively. While the drawdown in the observation wells constructed for second pumping well were ranged from $0.55 \mathrm{~m}$ to $0.49 \mathrm{~m}$ as highlighted in Table 4 . The drawdown and recuperation data were plotted in various diagram opined by eminent groundwater hydrologists (Cooper \& Jacob, Chow, Step Drawdown and Recuperation methods). The following Table 5 shows the aquifer characteristics deduced by different methods. 
Table 4. Drawdown versus yield (Long duration test-second pumping well)

\begin{tabular}{lllrllr}
\hline $\begin{array}{l}\text { Discharge } \\
\left(\mathrm{m}^{3} / \mathrm{hr}\right)\end{array}$ & $\begin{array}{l}\text { Drawdown (m) of } \\
\text { Main well (second } \\
\text { pumping well) }\end{array}$ & $\begin{array}{l}\text { Drawdown } \\
\text { Observation } \\
\text { constructed for } \\
\text { pumping well }\end{array}$ & $\begin{array}{r}\text { of } \\
\text { well-1 } \\
\text { second }\end{array}$ & $\begin{array}{l}\text { Drawdown } \\
\text { Observation }\end{array}$ & $\begin{array}{l}\text { constructed for } \\
\text { pumping well }\end{array}$ \\
\hline 120 & 4.88 & 0.55 & & 0.49 \\
\hline
\end{tabular}

Table 5. Aquifer Parameters for Main well, observation wells 1, 2 and 3 (for two wells)

\begin{tabular}{|c|c|c|c|c|c|c|c|c|c|}
\hline \multicolumn{10}{|c|}{ First Pumping well (Discharge-120 $\mathrm{m}^{3} / \mathrm{hr}$ ) } \\
\hline Methods & Cooper & $\& \mathrm{Jacob}$ & & Chow & & & Recul & ration & Average \\
\hline & Obs-1 & Obs-2 & Obs-3 & Obs-1 & Obs-2 & Obs-3 & $\begin{array}{l}\text { Main } \\
\text { well }\end{array}$ & $\begin{array}{l}\text { Obs- } \\
1\end{array}$ & \\
\hline \multicolumn{10}{|c|}{ Parameters } \\
\hline $\begin{array}{l}\text { Transmissivity } \\
\left(\mathrm{m}^{2} / \text { day }\right)\end{array}$ & 1198 & 1425 & 1632 & 926 & 1146 & 1508 & 1256 & & 1299 \\
\hline Storativity & 0.007 & 0.00365 & 0.01 & 0.01 & 0.0044 & 0.01 & - & - & 0.0075 \\
\hline $\begin{array}{l}\text { Radius of } \\
\text { Influence (m) }\end{array}$ & 324 & 428 & 211 & 200 & 336 & 183 & - & - & 280 \\
\hline \multicolumn{10}{|c|}{ Second Pumping Well (Discharge-120 $\mathrm{m}^{3} / \mathrm{hr}$ ) } \\
\hline $\begin{array}{l}\text { Transmissivity } \\
\left(\mathrm{m}^{2} / \text { day }\right)\end{array}$ & 2292 & 1647 & - & 1910 & 1180 & - & 1387 & - & 1683 \\
\hline Storativity & 0.0066 & 0.00194 & - & 0.00973 & 0.00309 & - & - & - & $\begin{array}{l}0.0053 \\
4\end{array}$ \\
\hline $\begin{array}{l}\text { Radius of } \\
\text { Influence (m) }\end{array}$ & 1096 & 1761 & - & 691 & 785 & - & - & - & 1083 \\
\hline \multicolumn{10}{|c|}{ Final Average } \\
\hline $\begin{array}{l}\text { Transmissivity } \\
\text { Storativity } \\
\text { Radius of Influe }\end{array}$ & $\begin{array}{l}\mathrm{n}^{2} / \text { day) } \\
\text { nce }(\mathrm{m})\end{array}$ & & & & & & & & $\begin{array}{l}1491 \\
0.0064 \\
682\end{array}$ \\
\hline
\end{tabular}

A perusal from the above Table 5 highlights that the average Transmissivity $(\mathrm{T})$ of the aquifer is $1491 \mathrm{~m}^{2} / \mathrm{d}$. The thickness of the aquifers, drawdown in water level as also quality of water during the long duration pumping tests, shows that the fresh water bearing aquifer underlain in the area is prolific. The quantum of flow along this thick aquifer has been obtained from the parameters like hydraulic gradient (i), transmissivity $(\mathrm{T})$ of the aquifer and length $(\mathrm{L})$ of the aquifer. Table 6 highlighted the drawdown, transmissivity, radius of influence as well as recuperation time against different yield. 
Table 6. Response of aquifer under pumping of main well against different discharge

\begin{tabular}{lllll}
\hline $\begin{array}{l}\text { Discharge } \\
\left(\mathrm{m}^{3} / \mathrm{hr}\right)\end{array}$ & Drawdown $(\mathrm{m})$ & $\begin{array}{l}\text { Transmissivity } \\
\left(\mathrm{m}^{2} / \text { day }\right)\end{array}$ & $\begin{array}{l}\text { Radius } \\
\text { influence } \\
(\mathrm{m})\end{array}$ & $\begin{array}{l}\text { Recuperation } \\
\text { time (hr) }\end{array}$ \\
\hline 50 & 1.81 & 523 & 30 & 2.24 \\
65 & 2.65 & 680 & 210 & 3.26 \\
75 & 3.19 & 784 & 973 & 5.29 \\
\hline
\end{tabular}

\subsection{Groundwater Quality of the study area}

The physicochemical and bacteriological analysis of groundwater was carried out as per standard water analysis methods (APHA). The physico-chemical and bacteriological parameters tested were $\mathrm{pH}$, Turbidity, Total Hardness (TH), Iron, Arsenic, Fluoride, Chloride, TDS, Calcium, Magnesium, Conductivity, Potassium, Carbonate, Bicarbonate, TC and FC. The results of physico-chemical analysis of water are presented in Table 7.

Table 7. Physico-chemical and bacteriological analysis of water sample from the pumping wells

\begin{tabular}{|c|c|c|c|}
\hline \multirow[t]{2}{*}{ Sl. No } & \multirow[b]{2}{*}{ Parameters } & \multicolumn{2}{|l|}{ Results } \\
\hline & & First pumping well & Second pumping well \\
\hline 1 & Turbidity, NTU & $<1$ & 10.5 \\
\hline 2 & pH Value & 7.32 & 7.21 \\
\hline 3 & $\begin{array}{l}\text { Total Hardness (TH) (as } \\
\left.\mathrm{CaCO}_{3}\right), \mathrm{mg} / 1\end{array}$ & 560 & 710 \\
\hline 4 & Iron (as Fe), mg/l & $<0.1$ & 1.15 \\
\hline 5 & Chloride (as Cl), $\mathrm{mg} / \mathrm{L}$ & 332.0 & 518.8 \\
\hline 6 & $\begin{array}{l}\text { Total Dissolved Solids (TDS) } \\
\mathrm{mg} / 1\end{array}$ & 886 & 1446 \\
\hline 7 & Calcium (as Ca) mg/l & 93.0 & 172 \\
\hline 8 & Magnesium (as Mg) $\mathrm{mg} / \mathrm{l}$ & 79.6 & 68 \\
\hline 9 & Arsenic (as As), mg/l & $<0.01$ & $<0.01$ \\
\hline 10 & Fluoride (as F), mg/l & 0.55 & 0.46 \\
\hline 11 & Conductivity, $\mu \mathrm{mhos} / \mathrm{cm}$ & 1,419 & 2170 \\
\hline 12 & Potassium (as K), mg/l & 5.7 & 6.10 \\
\hline 13 & Carbonate (as $\left.\mathrm{CaCO}_{3}\right), \mathrm{mg} / \mathrm{l}$ & NIL & NIL \\
\hline 14 & Bicarbonate (as $\left.\mathrm{CaCO}_{3}\right), \mathrm{mg} / 1$ & 341 & 295 \\
\hline 15 & $\begin{array}{l}\text { Total Coliform (TC) organisms, } \\
\text { MPN/100mL }\end{array}$ & 3.6 & $<1.10$ \\
\hline 16 & Faecal Coliforms, MPN/100mL & $<1.1$ & Absent \\
\hline
\end{tabular}

The water quality result indicates presence of TDS beyond desirable limit as per $\mathrm{BIS}$. The water has been found to be hard in nature having maximum $\mathrm{TH}$ as 710 
$\mathrm{mg} / \mathrm{L}$ as $\mathrm{CaCO}_{3}$ (beyond desirable limit). The chloride concentration has been found to be in higher concentration of $518 \mathrm{mg} / \mathrm{L}$ (maximum) which was more than desirable limit. Both calcium and magnesium have been found to be present in water in higher proportion (beyond desirable limit). The water has been found to be free from arsenic, fluoride as well as iron contamination. Though TC has been detected $(3.6$ per $100 \mathrm{ml}$ ) in the water sample but the said water has been found to be free from faecal contamination. In order to bring potability the groundwater needs to be treated for minimizing hardness and chloride. The water must be disinfected before supplying to the consumers. However, groundwater is fit for any constructional requirement.

\section{Conclusions and Recommendations}

Detailed study based on $1^{\text {st }}$ phase of hydrological study in and around the study area revealed that the aquifer, currently under pumping is also being tapped by $\mathrm{KMC}$ as well as by the population in the surrounding individual households as also by the medium to small housing societies. It will not be judicious to stress this aquifer, commonly under utilization by multiple users, from the sustainability and socio-economic points of view to meet the total requirement of the proposed site to be developed by KMC. At this juncture it may be recommended that in the first phase the urban establishment may be allowed to draw a maximum of $50 \mathrm{~m}^{3} / \mathrm{hr}$ from the aquifer already examined.

The total quantum of flow along the section within the geographical area of urban establishment has been derived as $7138 \mathrm{~m}^{3} /$ day based on $2^{\text {nd }}$ phase of hydrological study.

From comparison of the aforesaid data, it may be put forward that the volume of water per day what urban establishment may withdraw from the tube wells is limited to $15 \%$ of the quantum of flow flowing along the aquifer cross-section with the campus of eastern part of KMC area i.e. $1071 \mathrm{~m}^{3} /$ day. The value is fully conformable with the prescribed norms of Groundwater Estimation Committee (GEC), 1997 as opined by (CGWB, 1997). In the GEC norm (1984 \& 1997), 15\% of the groundwater resources in any area is allocated for drinking and other domestic purposes for livelihood. Now, it may be opined that the safe withdrawal of groundwater to the tune of $1071 \mathrm{~m}^{3} /$ day may be recommended.

Theis (1940) recognized that all groundwater of economic importance is in constant movement through a porous rock stratum, from a place of recharge to a place of discharge. He reasoned that under pristine conditions, aquifers are in a state of approximate dynamic equilibrium. 
Significantly, Theis (1940) distinguished between natural recharge and available recharge. Available recharge is the sum of unrejected and rejected recharge. The unrejected recharge is the natural recharge; the rejected recharge is the portion of available recharge rejected by an aquifer on account of being full. To assure maximum utilization of the supply, Theis argued that groundwater development should tap primarily the rejected recharge and, secondarily, the evapo-transpiration by non-productive vegetation. Thus, he defined perennial safe yield as equal to the amount of rejected recharge plus the fraction of natural discharge that it is feasible to utilize.

Recently, the emphasis has shifted to sustainable yield (Alley and Leake, 2004; Maimone, 2004; Seward et al., 2006). Sustainable yield reserves a fraction of safe yield for the benefit of the surface waters. There is currently a lack of consequences as to what percentage of safe yield should constitute sustainable yield. The issue is complicated by the fact that knowledge of several related earth sciences is required for a correct assessment of sustainable yield. Additionally, there are social, economic, and legal implications which have a definite bearing on the analysis.

A reasonably conservative estimate of sustainable yield would take all or suitable fractions of deep percolation. On a global basis, deep percolation is about $2 \%$ of precipitation. Sustainable yield may also be expressed as a percentage of recharge. Limited experience suggests that average percentages may be around $40 \%$ and with the least conservative around $70 \%$ (Ponce, 2007).

Keeping in view, the total volume of recharge may be available around $4547 \mathrm{~m}^{3}$ in the eastern part of KMC area by considering $2 \%$ of $1600 \mathrm{~mm}$ mean annual precipitation and $54 \%$ as open area. Thus it may be concluded that our recommended safe withdrawal of $1071 \mathrm{~m}^{3}$ is around $24 \%$ which is much below the average percentage of $40 \%$, as mentioned by Ponce, 2007. Hence our recommendation is well within the sustainable yield.

Moreover, it will be advisable not to withdraw groundwater more than $65 \mathrm{~m}^{3} / \mathrm{hr}$ at any point of time considering drawdown, radius of influence and recuperation time (Table 5). The pumping schedule should be made accordingly so that in a day maximum extraction of groundwater is limited to $1071 \mathrm{~m}^{3}$.

Some suggestive schedule for pumping may be: $65 \mathrm{~m}^{3} / \mathrm{hr}$ for $6 \mathrm{hr}$ a day for each of two pumps and the previous pumping well of capacity $50 \mathrm{~m}^{3} / \mathrm{hr}$ for $6 \mathrm{hr}$ a day but not exceeding maximum extraction of groundwater in the tune of $1071 \mathrm{~m}^{3}$ a day.

In addition, it may be well understood that the huge quantity of rainwater will be available in the roof top of urban establishment in the eastern part KMC area. It is expected that as per the guidelines, the proponent should go for rainwater harvesting for various purposes of gardening, fire fighting, car washing, toilet cleaning etc as well as some rainwater should be recharged into the exploited 
aquifer after necessary filtration and treatment. It will definitely help to conserve the water to a considerable extent.

In future, if the KMC may be in a position to provide piped water supply to the urban establishment to fulfill their water demand, it has to be ensured that the production wells must be properly sealed in such a fashion so that all pumping wells are not used further for withdrawing groundwater. Also, the production wells need to be sealed during construction against leaching of arsenic below approx. 80 $\mathrm{m}$ depth or below the sand zone in that vicinity but within impervious layer.

\section{References}

[1] Alley, W.M., and S.A. Leake. 2004. The Journey from safe yield to sustainability. Ground Water, Vol. 42, No.1, January-February, 12-16.

[2] Central Ground Water Board (CGWB).1997. Groundwater Resource Estimation Methodology, Report of the Groundwater Resource Estimation Committee (GEC), Ministry of Water Resources, Government of India, New Delhi.

[3] Kolkata Municipal Corporation (KMC). 2007. Groundwater Information Booklet, West Bengal.

http://cgwb.gov.in/District Profile/WestBangal/KolkataMunicipalCorporation.p df.

[4] Maimone, M. 2004. Defining and managing sustainable yield. Ground Water, Vo. 42, No. 6, November-December, 809-814.

[5] Mishra, A. and Ghosh, G. 2009. Scenario of groundwater resources of Kolkata Municipal Corporation area-analysis of the technical and legal aspects of the issues, Proceedings Regional Workshop on Groundwater related issuesWest Bengal, Andaman \& Nicobar Islands and Sikkim organized by Central Groundwater Board on $13^{\text {th }}$ and $14^{\text {th }}$ February, 2009, Eastern Region, Ministry of Water Resources, Govt. of India.

[6] Ponce, V.M. 2007. Sustainable Yield of Groundwater. California Department of Water Resources.

[7] Present Groundwater Scenario of West Bengal (PGWSWB). 2011. http://pradip-watercrisis.blogspot.in/2011/03/present-groundwater-scenario-ofwest.html

[8] Seward, P., Y. Xu, and L. Brenddock. 2006. Sustainable groundwater use, the capture principle, and adaptive management, Water Sa, Vol. 32, No. 4, October, 473-482. 
[9] Theis, C.V. 1940. The source of water derived from wells: Essential factors controlling the response of an aquifer to development. Civil Engineering, Vol. 10, No. 5, May, 277-280. 